\title{
Land Value Potential Zonation : Implication Towards Urban Planning
}

\author{
Revi Mainaki ${ }^{1}$, Anita Eka Putri ${ }^{1 *}$, Dwiyono Hari Utomo ${ }^{2}$ \\ ${ }^{1}$ Department of Geography Education, Faculty of Teacher Training and Education, \\ Universitas Siliwangi, Jl. Siliwangi No. 24, Kota Tasikmalaya 46115, Indonesia \\ ${ }^{2}$ Department of Geography Education, Faculty of Social Science, Universitas Negeri Malang, \\ Jl. Semarang 5, Malang, 65145, Indonesia \\ *Corresponding Author : anita.eka@unsil.ac.id
}

Received 15 April 2020/ Revised 7 August 2020 / Accepted 15 August 2020/ Available Online 22 August 2020

\begin{abstract}
Potential land prices are strongly influenced by various factors, Cimahi City has three subdistricts displaying unique characteristics, since it is located between two districts and one large city, which affects the potential price of land. The potential price of land is crucial to identify, especially in determining the policies of related agencies, the purpose of this research was to zoning potential land prices in Cimahi City. This study engaged a quantitative approach utilizing data collection technique in the form of observation, literature, documentation, and interviews, then analysis was conducted using a GIS which composed of assessment, weighting, coating, and buffering. The study population was all sub-districts in Cimahi. The research samples were taken from several sub-districts which were influenced by districts and cities characteristics indicators such as accessibility, land usage, and land ownership status. The results showed land prices potential was classified as low, medium, and high which was derived by several indicators. It could be concluded that the potential land price is strongly influenced by the surrounding area features, especially urban and district infrastructure.
\end{abstract}

Keywords: Land Value Potential; Zonation; Urban Planing

\section{Introduction}

Land is needed by humans for all forms of activities, especially for living and farming to meet their daily needs. Land ownership in Indonesia have been regulated in government policy related to the start of laws, legislation, government regulations, presidential regulations, presidential decrees and other technical rules (Virgo et al., 2011). Cimahi city presents unique characteristics to investigate how the land price is predicted, since Cimahi City is one of the bearers and directly adjacent to the city of Bandung with proximity of 12 $\mathrm{km}$ as the capital of West Java Province. Cimahi City is bordered by Bandung Regency and West Bandung Regency in the other side.

Ownership along with rapid development are determining the value of a particular currency, the more strategic or the closer residence to meet human needs, certainly the higher it gets to be paid. Land prices are mainly drived by several factors (Anggraini et al., 2015; 
Glaeser et al., 2005) namely (1) physical factors such as soil type, slope, elevation, land area and land utilization; (2) economic factorssuch as purchasing power, interests, amount of benefits offered, interest rates and land beneficial; (3) social factors namely population, security level and community lifestyle; (4) government factors namely taxes and related policies; (5) location and accessibility such asaccessibility towards education, health facilities, main roads, markets, transportation, mobility pace and etc; (6) availability of facilities for electricity networks, clean water, telephone networks, religious amenities, education, health and the tranquil spots.

A study result indicated that land prices are drawn by several factors (Fakhirah, 2010; Hidayanti, 2013) as follows (1) distance aspect upon road accessibility; (2) elevation aspect which correlates to temperature and water; (3) distance towards donwtown or main activities spots; (4) zoning; (5) mobility pace; (6) land topography; (7) land area, and (8) Land usage types. The land classification scheme to determine the price of land in a certain parameter including land purposed for (1) settlements; (2) trade and services; (3) industry; (4) transportation, communication and facilities; (5) a relatively complex trading industry; 6) urban areas within downtown and (7) urban areas within urban areas (Rusdi, 2013; Prabowo et al., 2016; Sasono \& Susetyo, 2018; Prihandoko, 2018). Land prices would possibly increase in accordance to the occurrence of economic activity that is correlated towards infrastructure such as roads, government financial and other activities in centrals (Rynjani \& Ragil, 2015).

The significant of zoning as a form of reconstruction is to estimate the potential price and to determine certain area performing a spatial approach. A research showed how zoning could be utilized as basic decision-making theories of the region's level of urgency (Hermawan \& Mainaki, 2019). Zoning could also be conducted using basic relics and other object indicators with reconstruction principle to determine the potential or forecasts of a particular are (Mainaki \& Hermawan, 2019). Once the zoning results are identified, the results are not only beneficial for decision making, but also could be used as a learning resource, as the map becomes a basis in identifying an area as a whole, to compherend the thoughts that would foster spatial intelligence. The results of this study could be used as one of the additional indicators in determining the purchase of shelter for the community in Cimahi as one of the growing centers (Hilman \& Mainaki, 2020; Rahayu \& Haryatiningsih, 2013).

The other side of Cimahi is bordered by West Bandung Regency, which is a new administrative area that has expanded, only a few years since the district was formed. This 
feature establishes the City of Cimahi occupies urban areas both within the middle of urban and in the suburbs. It has a relatively diverse area with social characteristics and physical potential, therefore land utilization determines the price of the land is relatively varied and has not been zoned in a wider scope area. Hence, land price predictions in Cimahi City which are essential information for urban planning and management (Koka et al., 2013).

A few researchers focused on development, since the potential price of land turns high or low. There have been limited studies concerned on a smaller scale and rarely utilized a regional approach, which was a draw back if a study attempted to analyze particular zone or region. Therefore, this current study aimed to describe the potential price of land in the form of reports and zoning maps engaging scoring and weighting on GIS, the purpose of this research was to zoning potential land prices in Cimahi City.

\section{Methods}

In order to analyze the potential of land prices in the City of Cimahi, this study employed a quantitative research approach using procedural steps based on the Geographic Information System (GIS). The basic analysis was performed for potential prices which later used as a feasibility study, as the indicators used in the study were based on relevant agency documentation research (Putri et al., 2020) namely (1) preliminary study to determine the topic, issues formulation, objectives and results to be obtained; (2) determine the research methodology and instruments development in accordance to collected data; (3) data collection was gained by documentation method were taken from (a) National Land Agency (BPN) of Cimahi City to obtain data regarding land ownership status, land use and land area, (b) Cimahi City Transportation Agency to obtain data relating to the existing road network in the city; supported by literature review and field observations based on documentation data to identify and strengthen research results referring to various scientific references, hence the basis of zoning grows vivid as it is founded upon theory (Mainaki \& Putri, 2020) data processing obtained relation upon the Geographic Information System (GIS) includes (a) scoring; (b) weighting; (c) determining the maximum score and weight to identify the range of scores (Kusumo \& Nursari, 2016; Gunawan et al., 2014; Siagiaan et al., 2015).

The analysis unit in this study was urban villages, thus the population was all urban villages in Cimahi City and the sample was several urban villages that displayed similar characteristics of one to two district. The potential land prices were determined using scoring 
and weighting tables (Table 1, Table 2, Table 3, Table 4, Table 5), the higher score means the higher potential land price and vice versa as the basis of map overlay is presented below:

Table 1. The Process Of Scoring Data Based On The Area of The Land or Building

\begin{tabular}{clccc}
\hline & \multicolumn{1}{c}{ Land Use } & \multicolumn{3}{c}{ Large } \\
\cline { 3 - 5 } No. & $\begin{array}{c}\text { Large } \\
\left(>10000 \mathrm{~m}^{2}\right)\end{array}$ & $\begin{array}{c}\text { Is being } \\
\left(1000-10000 \mathrm{~m}^{2}\right)\end{array}$ & $\begin{array}{c}\text { Narrow } \\
\left(<1000 \mathrm{~m}^{2}\right)\end{array}$ \\
\hline 1. & Rice fields & 3 & 2 & 1 \\
2. & Plantation & 3 & 2 & 1 \\
3. & Offices/Schools/Hospitals/Health & 3 & 2 & 1 \\
4. & Centers & 3 & 2 & 1 \\
5. & Factory/Industry & 3 & 2 & 1 \\
6. & Shops/Supermarkets/Markets & 3 & 2 & 1 \\
7. & Empty land & 1 & 1 & 1 \\
\hline
\end{tabular}

(Source: 2019, analysis results)

Table 2. The Process Of Scoring Data Based on Land Utilization

\begin{tabular}{clc}
\hline No. & \multicolumn{1}{c}{ Land Use } & Score \\
\hline 1. & Rice fields, plantations and vacant land & 1 \\
2. & Offices/schools/hospitals/health centers and settlements & 2 \\
3. & Shops/supermarkets/markets and factories/industries & 3 \\
\hline
\end{tabular}

(Source: 2019, analysis results)

Table 3. The Process of Scoring (Scoring) Data Based on Accessibility

\begin{tabular}{clccc}
\hline & \multicolumn{1}{c}{ Road Type } & \multicolumn{3}{c}{ Score } \\
\cline { 3 - 5 } No. & & $\begin{array}{c}\text { Close } \\
(<50 \mathrm{~m})\end{array}$ & $\begin{array}{c}\text { Is being } \\
(50-100 \mathrm{~m})\end{array}$ & $\begin{array}{c}\text { Far } \\
(>100 \mathrm{~m})\end{array}$ \\
\hline 1. & Distance to Frontage Road & 3 & 2 & 1 \\
2. & Distance to Boulevard & 3 & 2 & 1 \\
3. & Distance to Provincial Road & 3 & 2 & 1 \\
\hline
\end{tabular}

(Source: 2019, analysis results)

Table 4. Process of Scoring Data Based on Mastery of Land Ownership

\begin{tabular}{clc}
\hline No. Criteria & Score \\
\hline 1. & Right to Use (TNI HP) & 1 \\
2. & Right of Use (Mobile) & 2 \\
3. & Right to Build (HGB) & 2 \\
4. & Customary Property/Rights (HM/HMA) & 3 \\
\hline
\end{tabular}

(Source: 2019, analysis results)

Table 5. The Process of Weighting (Weight) Based on Map Effect

\begin{tabular}{clcl}
\hline No & Map & Weight & \multicolumn{1}{c}{ Information } \\
\hline 1 & Land Use & 3 & $\begin{array}{l}\text { The type of use and area of land greatly influences the value of } \\
\text { land and impacts on prices and determination of tax rates. } \\
\text { Affordability of land affects the value of the land and the } \\
\text { calculation of the tax rate. } \\
\text { To identify land tenure (property rights or state property) in } \\
\text { determining taxes. }\end{array}$ \\
\hline
\end{tabular}

(Source: 2019, analysis results) 
The overlay calculation for zonation is performed as follows: Minimum Total Score $=$ (Minimum Score of Land Area x Minimum Weight of Land Use Map) + (Minimum Land Use Score + Minimum Weight of Land Use Map) + (Minimal Score of Adjacency to Road x Minimum Weight of Road Network Map) + (Minimum Land Mastery Score X Minimum Weight of Status Map Land)

Minimum Total Score $=(1 \times 3)+(1 \times 3)+(1 \times 3)+(1 \times 2)=3+3+3+2=\underline{11}$

Maximum total score $=($ Maximum Land Area Score $\mathrm{x}$ Maximum Weight of Land Use Map) + (Maximum Land Use Score + Maximum Weight of Land Use Map) + (Maximum Score of Adjacency to Road x Maximum Weight of Road Network Map) + (Maximum Score of Land Mastery x Maximum Weight of Status Map Land)

Maximum Total Score $=(3 \times 3)+(3 \times 3)+(3 \times 3)+(3 \times 2)=9+9+9+6=\underline{33}$

Zonation Range :

$=\frac{\sum \text { Maximal Score }-\sum \text { Minimum Score }}{\text { Category }}$

$=\frac{33-11}{3}=\underline{7.33 \text { Rounded } 7}$

Hence, the zonation range is: 11 to $18=$ Low Land Price Potential; 19 to $26=$ Potential Medium Land Prices; 27 to 33 = Potential High Land Prices.

\section{Results and Discussion}

Land utilization in the city of Cimahi (figure 1) presented practically similar characteristics of land use in each village that was dominated with settlements, rice fields and plantations. However, in the south side were relatively large industrial and shopping areas which indicated on how the southern part gained the potential for higher land prices compared to central and northern parts. The northern part is bordered by West Bandung Regency while the southern part is bordered by Bandung City. Hence, considering both the land utilization and location, the south side seemed promising higher price potential and vice versa occurred upon the north that obtained lower price potential.

The road network in Cimahi (figure 1) has been relatively wide-spread, as each place was connected with local avenue and highway. The central part was cut across over provincial road in a single direction, that way the South was remarkably more strategic than north. The south was through fare towards provincial road one-way and two-way, making it more strategic than the central and northern parts of Cimahi. This phenomenon explains why 
the south has higher potential land prices according to the road network adjacency and accessibility upon low to high, namely the north, center and south.

According to land ownership status (figure 1) in the north and south, most of them earned the land ownership/customary ownership rights status. In the southern part obtained land utilization rights, where the central part obtained of land use rights status (military),as Cimahi as a Military basis in the sense of the community implying that the middle part was inventory or land of country that was only function for military. The northern and southern displayed interests for the benefit upon other human activities, means the northern and southern parts will likely draw a higher potential land price compared to the central part of Cimahi City.

Potential land prices (figure 2) in the north or Cimahi Utara sub-district used Pasirkaliki sub-district as sample possed regular or irregular residential or irregular land use conditions and rice fields, the land use status of all customary property rights. This urban village presented practically similar characteristics as other urban villages in North Cimahi Sub-district. It endowed potential high land prices of customary property rights status, in term of residential or regular land utilization and relatively adjacent towards the road based on distance factor, while areas with potential taxes were customary land/customary land status with regular and relatively moderate or far-off residential land use by road.

Based on the analysis conducted to the middle section with Setiamanah Village as a sample that displayed identical characteristics towards other urban villages within Central Cimahi Sub-district, it could be concluded that Setiamanah and other urban villages within the central part of Cimahi City enjoyed high and medium land prices, most of which were potentially due to land use of military status of usufructuary rights (government land). The other minority gained high potential price, since those earned customary land/customary rights status. The sample of the southern part or the southern district of Cimahi in the current study was the Cibeber Village, with land status, land use and various road conditions as appeared in other villages in the southern part of Cimahi City. The administrative map, land status, land use and road network of Cimahi City is presented be on figure 1 . 
Revi Mainaki et al / GEOSI Vol 5 No 2 (2020) 288-300

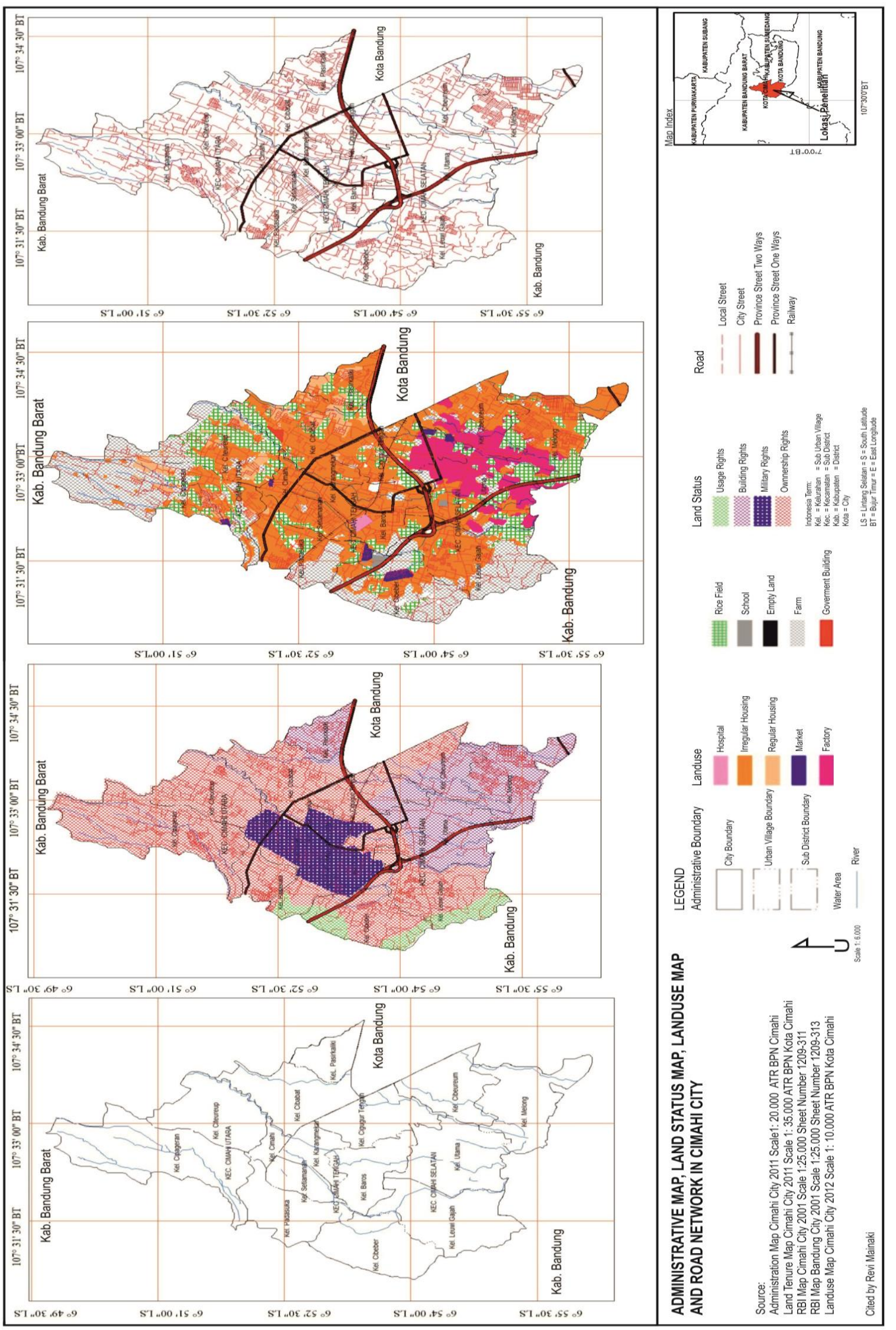

Figure 1. Administrative map, land status, land use and road network of Cimahi 


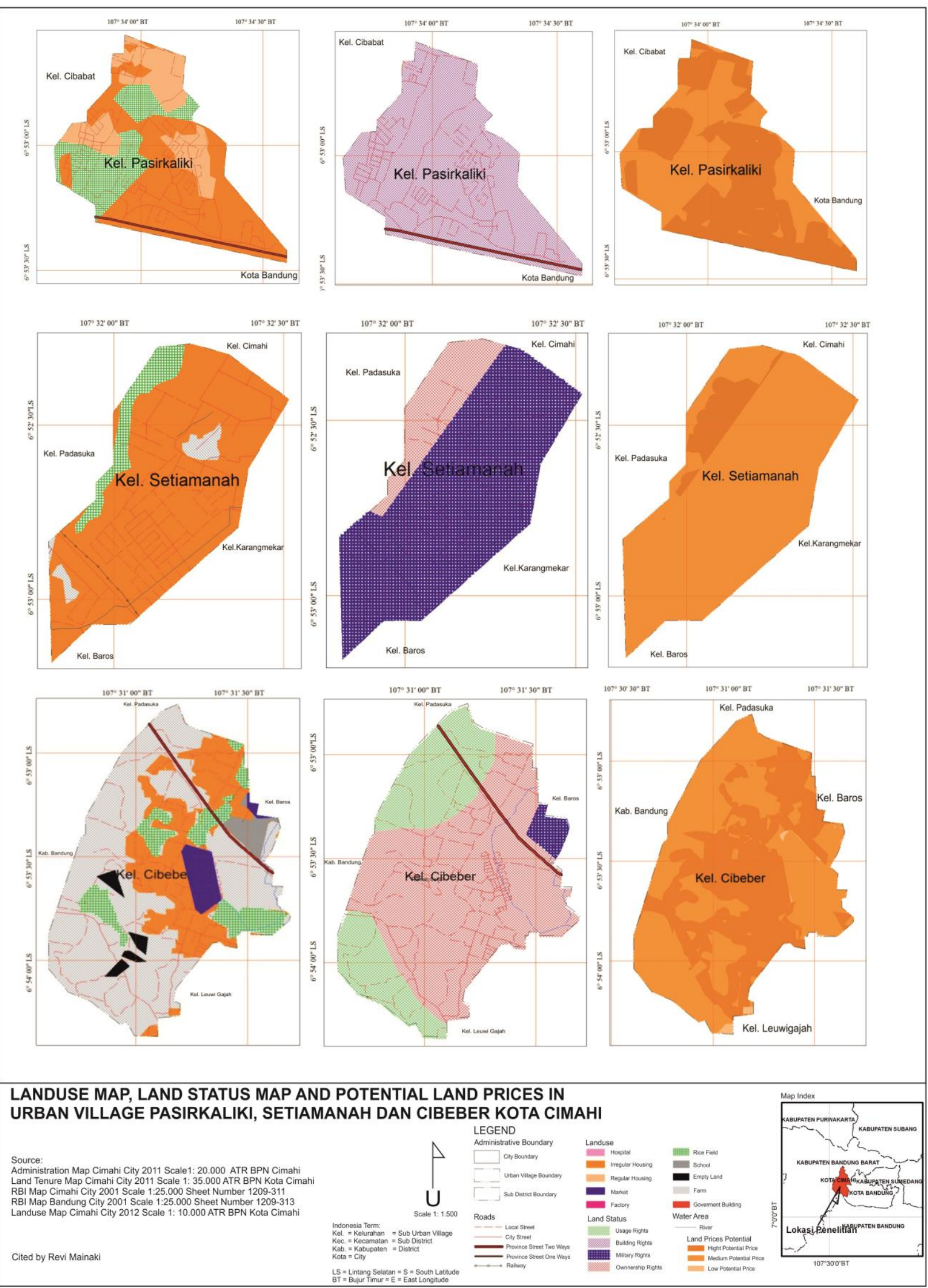

Figure 2. Map of land use, land status, potential land prices in Pasirkaliki, Setiamanah and Cibeber Villages in Cimahi City 
Cibeber sub district demonstrated a relatively diverse land prices potential (figure 2). The potential high price was expected for land with customary property rights status, strategically adjacent towards one or two-way provincial roads, supported with residential and industrial/market land use. Land use is the land with right to establish building or military base, while the potential for low land prices was presented with the condition upon usufructuary land status of employment for paddy fields or plantations and relatively remote towards the main road in accordance with the direction of proximity to the road.

Considering the influence of land status, land use, adjacency, and land accessibility, Cimahi City endowed potential of land prices across north to south. In the north side was potentially possess low prices, while in the south showed higher value, and in middle had more diverse potential land prices. The map of landuse, land status, and potential land prices in Pasirkaliki, Setiamanah and Cibeber Village in Cimahi City is presented on figure 2.

The results showed that potential for the low, medium and high land potential prices within Cimahi City were strongly influenced whether by road network or land utilization in the term of urban village surroundings. Land status affects the land prices potential, however not by two other aspects. This result is in accordance with research conducted by Fakhirah (2010) and Hidayanti (2013) which land prices were drawn by (1) distance aspect towards road accessibility; (2) elevation aspect that relates to temperature and water; (3) accessibility towards center of activities or activities; (4) zoning; (5) mobility pace; (6) land topography; (7) land area and (8) land use type.

The result also comformable towards Rusdi (2013); Prasetya \& Sunaryo, (2013); Sasono \& Susetyo (2018); Prihandoko (2018) which described the land classification scheme to determine the land price in a certain parameter, namely land use for (1) settlements; (2) trade and services; (3) industry; (4) transportation, communication and facilities; (5) a relatively complex trading industry; (6) urban areas within downtown and (7) urban within the urban areas. The results showed the correlation between several studies in a single result with a specific area and broader approach (regional approach).

This result is in accordance with research conducted by Elmanisa et al. (2017) examined land prices across Jakarta, Bogor, Depok, Tanggerang and Bekasi or abbreviated as Jabodetabek illustrated how land prices in these areas were relatively high due to resources and infrastructure, especially within metropolitan area of the capital. In Indonesia, there are several areas with zoning potential for research land, as urban areas in Cimahi City gained relatively high land prices which tended to be close to Bandung City as the capital area of 
West Java Province and otherwise, it tended to below or moderate once the areas were rather remote towards Bandung City or closer to urban areas.

This research is also in line with the research of Hidayanti (2013) that engaged highresolution satellite image analysis to zoning land prices in Jetis District, Yogyakarta utilizing relatively similar indicators. The results are quite equal, which strengthened the research results of Cimahi City with relatively similar results are obtained. Therefore, the results of this study could be utilized as a general reference for upcoming research regarding zoning potential land prices in various regions. In contrast to research of Masykuroh \& Rudiarto (2016) which attempted on changes in land prices, as there was an effect highway development, in this case is accessibility aspect. There was an increase of land prices towards the area nearby the road or highway gate of Ungaran. The result supports the research undertaken,since accessibility aspect significantly affects the potential price of land. Research of Rahati et al. (2015) is also in line with this study, as the occurrence of land damage due to natural disasters had greatly reduced land prices, certainly, it is related to the physical aspect that is being affected by the damage and causes material loss.

Based on the research discussions according to several other studies, this study presents a parallel and general position, what distinguishes this study from other research is that the location demonstrates intriguing characteristics. In this study of Cimahi City, which represented an area that obtain characteristics established upon cities and districts.

\section{Conclusion}

All over areas in Cimahi City obtained a road construction network that was relatively evenly crossed by city roads, sub-district roads and provincial roads. The southern part of Cimahi City possed an area that was supported with Bandung city namely factories, shophouses and industrial areas, where the land status was dominated by ownership and user rights,therefore most land prices were relatively high. The central area was dominated by settlements and military areas utilization with land status dominated by military rights. Hence, most areas displayed the potential for moderate land prices as those were the central controlled by municipalities or regencies, while the northern part was dominated by open land use such as plantations and land. Rice fields ownership and use rights, thus most of the potential land prices were low and moderate due to excess, by the district area. 


\section{Conflict of Interests}

The authors declare that there is no conflict of interest with any financial, personal, or other relationships with other people or organizations related to the material discussed in the article.

\section{Acknowledgment}

We would like to express our gratitude to Universitas Pendidikan Indonesia, specifically Bachelor Degree Programs that have provided us opportunities to perform research and formulated the journal articles.

\section{References}

Anggraini, S., Prawira, Y. C. S., Untung, M., \& Indonesia, P. (2015). Estimated The Reasonable Land Price in Industrial Estate: Case Study of an Industrial Estate in Jakarta. FIG Working Week. Sofia, Bulgaria.

Elmanisa, A. M., Kartiva, A. A., Fernando, A., Arianto, R., Winarso, H., \& Zulkaidi, D. (2017). Land price mapping of Jabodetabek, Indonesia. Geoplanning: Journal of Geomatics and Planning, 4(1), 53-62.

Fakhirah. (2010). Identifikasi Faktor yang Mempengaruhi Nilai Jual Lahan dan Bangunan pada Perumahan Tipe Sederhana. Jurnal SMARTek, 8(4), 251-269.

Glaeser, E. L., Gyourko, J., \& Saks, R. (2005). Why is manhattan so expensive? Regulation and the rise in housing prices. Journal of Law and Economics, 48(2), 331-369. https://doi.org/10.1086/429979.

Gunawan, D; Hartanti, S \& Maulana, Y. (2014). Rancang Bangun Aplikasi Analisis Kredit Menggunakan Metode Skoring Pada Bintang Jaya Variasi Audio. Jurnal Sistem Informasi, 3(2), 97-103.

Hermawan, I \& Mainaki, R. (2019). Pemetaan Jalur Dan Tinggalan Perkeretaapian Masa Kolonial Belanda di Wilayah Cirebon Timur. Jurnal Sosioteknologi, 18(3), 560-574.

Hidayanti, I. (2013). Analisis Harga Lahan Berdasarkan Citra Penginderaan Jauh Resolusi Tinggi. Jurnal Pendidikan Geografi GEA, 8(4), 57-71.

Hilman, I \& Mainaki, R. (2020). Advantage Of Map As Geography Learning Media To Enhance Students Spatial Intelligence. Internasional Journal of Geomate, 18(68), 225232.

Koka, N; Monkkonen, P \& Quigleyc, G. (2013). Land Use Regulations and The Value of Land and Housing; An Intra-Metropolitan Analysis. Journals of Urban Economic, 81(2), 136-148. https://doi.org/https://doi.org/10.1016/j.jue.2014.03.004.

Kusumo, P \& Nursari, E. (2016). Zonasi Tingkat Kerawanan Banjir dengan Sistem Informasi 
Geografis pada DAS Cidurian Kabupaten Serang, Banten. Jurnal String, 1(1), 29-38.

Rahati, M., Kahar, S., \& Subiyanto, S. (2015). Analisis Perubahan Zona Nilai Tanah Kaitannya Dengan Banjir Di Kecamatan Pedurungan Kota Semarang. Jurnal Geodesi Undip, 4(1), 117-128.

Mainaki, R \& Hermawan, I. (2019). Perkeretaapian Masa Kolonial Belanda di Wilayah Indramayu: Pemetaan Jalur dan Bukti Tinggalan Arkeologis. Jurnal Walennae, 17(2), $125-142$.

Mainaki, R \& Putri, A. (2020). Paleogeografi: Perkembangan Keanekaragaman Hayati Dalam Ruang dan Waktu (Biodiversity In Time And Space). Jurnal Geografi, Edukasi Dan Lingkungan, 4(1), 17-24.

Masykuroh, D. K., \& Rudiarto, I. (2016). Kajian Perubahan Penggunaan Lahan dan Harga Lahan di Wilayah Sekitar Pintu Tol Ungaran. Tataloka, 18(1), 53-66.

Prabowo, S., Hamid, D., \& Prasetya, A. (2016). Analisis Partisipasi Masyarakat Dalam Pengembangan Desa Wisata (Studi Pada Desa Pujonkidul Kecamatan Pujon Kabupaten Malang). Jurnal Administrasi Bisnis S1 Universitas Brawijaya, 33(2), 18-24.

Prasetya, N \& Sunaryo, B. (2013). Faktor-Faktor yang Mempengaruhi Harga Lahan Di Kawasan Banjarsari Kelurahan Tembalang, Semarang. Jurnal Teknik PWK, 2(2), 223232.

Prihandoko, T. (2018). Analisis Nilai Lahan Kecamatan Mergangsan Kota Yogyakarta Menggunakan Aplikasi SIG dan Penginderaan Jauh. Jurnal Pendidikan Geografi UMS, 13(1), 1-14.

Putri, A. E., Utomo, D. H., \& Mainaki, R. (2020). Analisis kesesuaian lahan rawa untuk pengembangan kawasan permukiman di Kecamatan Gondang Kabupaten Tulungagung. Jurnal Pendidikan Geografi: Kajian, Teori, dan Praktek dalam Bidang Pendidikan dan Ilmu Geografi, 25(2), 170-178.

Rahayu, M \& Haryatiningsih, R. (2013). Persepsi Masyarakat dalam Menentukan Tempat Tinggal: Kota Cimahi Sebagai Pusat Pertumbuhan. Jurnal Kajian Ekonomi Dan Pembangunan, 9(2), 58-71. https://doi.org/DOI: https://doi.org/10.29313/.v9i2.2305.

Rusdi, M. (2013). Faktor-faktor yang Mempengaruhi Harga dan Penggunaan Lahan di Sekitar Jalan Lingkar Salatiga. Jurnal Pembangunan Wilayah Dan Kota, 9(3), 317-329. https://doi.org/https://doi.org/10.14710/pwk.v9i3.6543.

Rynjani, G \& Ragil, H. (2015). Kajian Harga Tanah Dan Penggunaan Lahan Di Kawasan Perdagangan dan Jasa Kelurahan Lamper Kidul, Kota Semarang. Jurnal Teknik PWK, $4(3), 417-427$.

Sasono, M \& Susetyo, C. (2018). Analisis Potensi Perubahan Pemanfaatan Lahan Berdasarkan Model Spasial Harga Lahan di Kecamatan Tembelang Kabupaten Jombang. Jurnal Teknik ITS, 7(1), 60-65. 
Siagiaan, T; Sudarsono, B \& Wijaya, A. (2015). Evaluasi Kriteria Kesesuaian Lahan Permukiman Dengan Analitycal Hierarchy Process (Studi Kasus :Kecamatan Boja dan Kecamatan Limbangan Di Kabupaten Kendal). Jurnal Geodesi Undip, 5(1), 107-115.

Virgo, E; Mahendra, A; Rusmawar, W \& JP, T. (2011). Land Value Indexation in Indonesia: A Pilot Study in Pontianak City. Facing The Challenges-Building the Capacity Congress. Proceeding FIG Congress. 